\begin{tabular}{c}
\hline KeMAS 12 (2) (2017) xx-xx \\
Jurnal Kesehatan Masyarakat
\end{tabular}

\title{
IMPROVING ELDERLY'S DENTAL HYGIENE THROUGH NURSING HOME STAFF'S DENTAL HEALTH EDUCATION AT THE NURSING HOME
}

\author{
Bedjo Santoso ${ }^{\bowtie}$, E. Aryati Eko Ningtyas, Diyah Fatmasari
}

Jurusan Keperawatan Gigi Poltekkes Kemenkes Semarang

\section{Article Info}

Article History:

Submitted 12 October 2016

Accepted 17 January 2017

Published January 2017

Keywords:

elderly; knowledge; at-

titude; skill; nursing

home staff; dental hygiene

DOI

http://dx.doi.org/10.15294/

kemas.v11i1.3521

\begin{abstract}
Stomatitis often occurs in elderly at nursing home. They need nursing home staff assistance to maintain their dental and oral health. Therefore, nursing home staff need dental health education. Lecture or discussion methods, which are more effective to improve knowledge, attitude and skill of nursing home staff was the purpose of this research. The research design was quasi-experiment research and pretest-posttest with control group. The sample was 42 nursing home staffs and 74 elderlies, divided into two groups, consisted of 18 nursing home staffs and 33 elderlies using lecture method. Another group consisted of 24 nursing home staffs and 41 elderlies using discussion method. Validity was tested with product moment. Questionnaire of knowledge, attitude and skill correlation was $0.4725-0.6853 ; 0.4772-0.6962$ and $0.3100-0.4916$. Reliability test with Alpha Cronbach was $0.9292 ; 0.9273 ; 0.792$. Research result was lecture and discussion methods were effective to improve knowledge, attitude and skill of nursing home staff to increase elderly's dental hygiene. The research concludes that discussion method is effective to improve knowledge while lecture is more effective to improve attitude and skill of nursing home staff.
\end{abstract}

\section{Introduction}

Limitation of the elderly age according to some experts divided into several grouping, one age limit is person who aged above 60 years. According to Law No. 4 year 1965, the elderly are those aged 55 years and over, therefore in Indonesia retirement age start at 55 years old, which means that at the age of 55 years is considered that the productivity have reduced (Lumentut, 2013). Effect of aging process causes many problems, such as physic biological, mental and social economy, including changes in oral health status (Tjeckyan, 2014).

Oral health problem that affects many elderly are dental caries, tissues supporting the teeth and soft tissue in the mouth such as stomatitis and the problem of the use of denture (Molton, 2014). The condition is caused by several factors, one of which is poor hygiene of dental and oral. It fits the opinion Petersen (2010), which stated that the elderly living in nursing homes have oral health status worse than the elderly living at home alone, therefore it requires special care (Molton, 2014). Nursing home is a place of elderly accommodated to get comprehensive services including health care, the main function of the nursing home is for revalidation or reactivation of elderly (Marson, 2014). Results of preliminary studies conducted showed that $56.8 \%$ elderly did not wear dentures with an average of 1.7 index debris. There were $37.8 \%$ elderly who wear complete dentures with 
an average of 2.1 index debris.

Maintenance of oral health of elderly can't be done by elderly independently but need the help of others (Petersen, 2010), it is because the physical and psychological deterioration experienced by elderly (Molton, 2014). People who are directly related to the health care of elderly in a nursing home are elderly caregiver (Pramurukti). Elderly caregiver is people who get certain education to take care of elderly (Frenkel, 2001). Efforts to prevent oral health problems of elderly can be achieved through dental health education to elderly caregiver by using a lecture and discussion (Rahman, 2011). Effectiveness of dental health education, which is given by lecture or discussion methods are still has opinion disagreement, some researchers argue that lectures is more effectively used as a method of health education (Webster, 2015), other researchers found the discussion more effective in improving knowledge, attitudes and skills (Rahman, 2011). Based on these differences, it is necessary to do research on the effectiveness of dental health education between lecture and discussion. This study aims to determine the effectiveness of dental health education using lecture and discussion methods to increase knowledge, attitudes and skills of elderly caregiver in improving the oral health of elderly in nursing home.

Method

This research was a quasi experiment with non equivalent control group design with pre test and post test (White, 2014). The design of this research began with the initial observation to determine knowledge, attitudes and skills of elderly caregiver about oral hygiene maintenances; we performed pretest prior to dental health education with lecture and discussion method, accompanied by inspection of elderly oral hygiene in a nursing home. Dental health education carried out for 3 months, after completion of the posttest- 1 and examination of dental and oral hygiene elderly, one month later after the dental health education, carried out post-test 2. Observations carried out during the four months, according opinion of Amanah (2007), which stated that the change in behavior after participating in education can be measured between 3-6 months, with the purpose to determine the learner achievement of the material taught during training.

The population in this study was 100 elderly caregivers from 8 nursing homes in Semarang city. Samples were taken with accidental sampling method, we obtained as many as 42 people which divided into two groups consisting of 18 elderly caregivers from Elim nursing home which given training by lectures and 24 elderly caregivers from Pengayoman nursing home which given training by discussions. Criteria: a) perform basic tasks as elderly caregiver, 2) live in a dorm of Pengayoman and Elim nursing home, 3) had not received education and training on oral health, 4) aged between 18-35 years. Object of research was the elderly who live in Elim and Pengayoman nursing home aged over 55 years, can perform the daily activity by themselves, and had a natural or imitation tooth.

The dependent variable in this study was dental health education with lecture and discussion methods. The independent variable were 1) Knowledge which measured by a questionnaire; 2) Attitudes which measured with Likert scale, 3 ) Elderly caregiver skill about dental and oral hygiene maintenance measured with skill check list, and 4) Examination of dental and oral hygiene elderly measured by Plaque index (IP). Normality test results obtained $p$-value $=0.626$, so the data were tested using independent t-test, with significance level $a<0.05$.

Instruments in this study were a questionnaire to measure knowledge, Likert scale to measure attitudes and a check list to measure skills. Previously, we tested the instrument on 20 elderly caregivers in Hethany nursing home Semarang. Measurement validity was analyzed with Pearson product moment analysis with 0.05 significant level. Knowledge variable was measured by a questionnaire consisting of 39 items of questions, 33 items declared valid by the correlation between the range of 0.4725 to 0.6853 and 6 questions disqualified by the correlation range below 0.4725. Valid question items then tested the reliability with Alpha method with a value of 0.9292. Attitude variable was measured using a Likert scale with 25 questions, which 22 items declared valid by the correlation between the range from 0.4772 to 0.6962 and the 3 
questions disqualified with a range correlation below 0.4772 . Valid question items then tested the reliability with Alpha method with a value of 0.9273 . Skills variable was measured by instrument consists of 22 items declared valid by the correlation between the range of 0.3100 to 0.4916. Valid questions items then tested the reliability with Alpha method with a value of 0.792. Dental and oral hygiene of elderly measured using plaque index (PI)

\section{Results and Discussion}

This research has been carried out stages of ethical clearances and approved by the Ethics Committee of Dentistry, Faculty of Dentistry, Universitas Gadjah Mada.

Characteristics of respondents in this study include age and education level, can clearly be seen in the following description:

Results of measurement of the variables age, the average age for the group obtained 25.88 lectures and discussion groups 25.25. Chi-square test results showed $\mathrm{x} 2=4.161, \mathrm{p}=$ 0.526 ( $p>0.05$ ), mean age variable both groups there was no significant difference. Domination age variation in both groups were aged 21-25 years. Based on the test results of these data we can conclude that the age of the two treatment groups showed comparable or comparable.

Long education research subject, after the chi-square test $\mathrm{x} 2=1.480, \mathrm{p}=0.687(\mathrm{p}>0.05)$ shows that the educational level in both groups there was no significant difference. Variations in the length of education in both groups were dominated by the 12-year education period. Long distance education that respondents in both groups showed comparable or comparable.

The mean scores of knowledge, attitudes and skills before treatment (pre-test) on both lectures and discussions showed no statistically significant difference $(p>0.05)$. This means that the initial conditions of knowledge, attitudes and skills of elderly caregiver about dental and oral hygiene maintenance is no difference or comparable.

It showed that the characteristics of the respondent in a comparable state (homogeneous), that means before the intervention it was required to determine the initial conditions of each group, whether the initial conditions were comparable, because the sampling homogeneous used may reduce variation and simplify data analysis (Teddlie, 2007). With homogeneous conditions, elderly caregiver have the same characteristics so

Table 1 . Homogeneity Characteristics of Respondents

\begin{tabular}{|c|c|c|c|c|c|c|c|c|}
\hline \multirow{3}{*}{ Variable } & \multicolumn{8}{|c|}{ Group } \\
\hline & \multicolumn{3}{|c|}{ Lecture } & \multicolumn{3}{|c|}{ Discussion } & \multirow{2}{*}{$\mathrm{X}^{2}$} & \multirow{2}{*}{$\mathrm{p}$} \\
\hline & $\mathrm{f}$ & $\%$ & mean \pm SD & $f$ & $\%$ & mean \pm SD & & \\
\hline \multicolumn{9}{|l|}{ Age } \\
\hline $15-20$ & 5 & 27,8 & $25,88 \pm 8,0825$ & 5 & 20,8 & $25,25 \pm 8,8526$ & 4,161 & 0,526 \\
\hline $21-25$ & 8 & 44,4 & & 12 & 50 & & & \\
\hline $26-30$ & 1 & 5,6 & & 4 & 16,7 & & & \\
\hline $31-35$ & 2 & 11,1 & & 0 & 0 & & & \\
\hline $36-40$ & 1 & 5,6 & & 1 & 4,2 & & & \\
\hline $41-45$ & 0 & 0 & & 0 & 0 & & & \\
\hline $46-50$ & 1 & 5,6 & & 2 & 8,3 & & & \\
\hline \multicolumn{9}{|c|}{$\begin{array}{l}\text { Education length } \\
6\end{array}$} \\
\hline 9 & 1 & 5,6 & $11,7 \pm 2,0073$ & 2 & 8,3 & $10,86 \pm 1,9406$ & 1,480 & 0,687 \\
\hline 12 & 4 & 22,2 & & 5 & 20,8 & & & \\
\hline \multirow[t]{2}{*}{15} & 12 & 66,7 & & 17 & 70,8 & & & \\
\hline & 1 & 5,6 & & 0 & 0 & & & \\
\hline Knowledge & & & $24,72 \pm 4,226$ & & & $24,38 \pm 2,683$ & & 0,747 \\
\hline Attitude & & & $71,22 \pm 4,008$ & & & $68,17 \pm 6,787$ & & 0,076 \\
\hline Skill & & & $11,50 \pm 3,777$ & & & $13,75 \pm 4,346$ & & 0,087 \\
\hline
\end{tabular}

Source : Primary Data 
that the capability to receive dental health education materials provided through lecture and discussion methods in an effort to change behavior to improve oral hygiene elderly.

Table 2 shows elderly caregiver in Elim nursing home given dental health education with the lecture method, from the pre-test to post test 1 and pre-test to post-test $2(p<0.05)$ showed a significant increase in the value of knowledge, increased knowledge from post test- 1 to post test- 2 , statistically $(p=0.385)$ showed no significant increase in the value of knowledge. Improved knowledge elderly caregiver in Pengayoman nursing home given dental health education with discussion method, the value of the pre-test to post-test-1, post test- 1 to post test- 2 and pre-test to post-test 2 showed an increase in the value of knowledge was significant $(p<0.05)$.

Elderly caregiver is the key to success in improving the knowledge, attitudes and skills maintenance of oral hygiene of elderly. Elderly caregiver existence in a nursing home is very strategic because it can act as caregiver, educator, to help overcome the problems of oral health of elderly as well as supervisors in healthy living behavior. Dental health education will affect the knowledge, attitudes and skills of elderly caregiver, after elderly caregiver know and be able to practice the maintenance of oral hygiene, is expected to lead to a positive attitude or consciousness that encourages elderly caregiver to behave according to their knowledge and skills possessed, so as to transfer of knowledge and transfer of skills to the elderly.

No increase in the value of knowledge in lectures due to elderly caregiver group did not understand the material presented. Elderly caregiver considers the material presented is a new thing, so it takes time to adapt. In a lecture, the targets are not given the opportunity to dialogue with presenter, so that if the target does not understand the material is difficult to obtain clarification, the interactions that occur tend to be centered (centered on the presenter), presenter not knowing for certain the extent to which the target controlled substance lectures, goals less grasp what is meant by a presenter, not giving a chance to the target to solve the problem, failed to give opportunity to the target to develop the skills and opportunity of expression, presenter more active while the target being passive.

Lectures are conventional methods in health education, so it has several weakness including: a) when frequently used can lead to bad habits, namely the nature of the passive, inactive for search and manage information; $b$ ) only a messenger can be a good speaker; c) not all the targets have a good grasp of; d) often cause verbalism of the target, they can say but do not know what it means; e) often misunderstood because the target misunderstand the meaning of the description extension; f) listen to a lecture in a long time can lead to boredom (Rahman, 2011; Kaur, 2011).

Elderly caregiver feel bored while listening to dental health education, which can lead to boredom. Individuals who feel bored while listening to counseling tend to perform useless actions to relieve the boredom, sometimes people are sick and tired tend to sleepy at the time of dental health education carried out, so do not understand the material presented by the speaker. According to Hidayati (2014), a person who is tired of receiving the

Table 2. The Mean of Knowledge, Attitudes and Skills of Elderly Caregiver

\begin{tabular}{|c|c|c|c|c|c|c|c|c|c|c|c|c|}
\hline \multirow{3}{*}{ Group } & \multicolumn{4}{|l|}{ Knowledge } & \multicolumn{4}{|l|}{ Attitude } & \multicolumn{4}{|l|}{ Skill } \\
\hline & Lecture & & Discussion & & Lecture & & Discussion & & Lecture & & Discussion & \\
\hline & $\begin{array}{l}\text { Mean } \\
\text { difference }\end{array}$ & $\mathrm{p}$ & $\begin{array}{l}\text { Mean } \\
\text { difference }\end{array}$ & $\mathrm{p}$ & $\begin{array}{l}\text { Mean } \\
\text { difference }\end{array}$ & $\mathrm{p}$ & $\begin{array}{l}\text { Mean } \\
\text { difference }\end{array}$ & $p$ & $\begin{array}{l}\text { Mean } \\
\text { difference }\end{array}$ & $p$ & $\begin{array}{l}\text { Mean } \\
\text { difference }\end{array}$ & $\mathrm{p}$ \\
\hline $\begin{array}{l}\text { Pretest- } \\
\text { posttest } 1\end{array}$ & 2,78 & 0,026 & 3,54 & 0,000 & 4,17 & 0,001 & 1,04 & 0,432 & 19,44 & 0,000 & 17,83 & 0,000 \\
\hline $\begin{array}{l}\text { Posttest-1 } \\
\text { Posttest-2 }\end{array}$ & 0,39 & 0,385 & 1,08 & 0,020 & 1,00 & 0,024 & 3,46 & 0,029 & 0,44 & 0,203 & 0,92 & 0,029 \\
\hline $\begin{array}{l}\text { Pretest - } \\
\text { Posttest-2 }\end{array}$ & 3,17 & 0,010 & 4,63 & 0,000 & 5,17 & 0,000 & 4,50 & 0,002 & 19,89 & 0,000 & 18,75 & 0,000 \\
\hline
\end{tabular}

Source : Primary Data 
information conveyed through the lecture in too long time and not varied will impact on the lack of understanding of the material received.

Boredom in dental health education will reduce a person's interest in the maintenance of oral hygiene, so the impact on low mastery of the material and a decrease in learning achievement. This is evidenced by Hamidah (2012), in her research shows that the higher the interest and intelligence of a person, then the higher the academic achievement.

Someone with a high interest likely to be active in every activity. factors affecting the activeness of elderly caregiver in doing the transfer of knowledge and transfer of skill (Elizabeth, 2010), are behavioral factor determined or formed from three factors, namely: 1) the predisposing factors are factors that facilitate or predispose to the occurrence a person's behavior, 2) enabling factors are factors that enable or facilitate behaviors or actions, 3) reinforcing factor are factors to encouraging or reinforcing the behavior.

Although both methods can improve knowledge ( $p=0,000$ in discussion groups and $p=0.010$ in lectures group), but the group discussion group had more significant than lectures group, as evidenced from the average value of the difference between a discussion group was higher than lecture group. Method of discussion is the process of delivery of material between sources and targets to hold a dialogue together to seek solutions and to absorb and analyze a particular material.

Health education with discussion method allows for interaction between the resource with the target, and the speaker and hold a dialogue together to seek solutions and to absorb and analyze one or a group of a particular material. According to Rizki (2012) and Rahman (2011), discussion method has advantages: 1) provide the opportunity for participants to discuss issues so that participants can express their opinions, 2) participants "forced" by circumstances to pay attention to the explanation of others in discussing the problem, 3) participants can respond opinion of speakers and other participants , 4) the results of the talks can be formulated by a moderator / speaker so that the participants can know. 5) can be collected opinions and different responses on the issues discussed and solutions.

Discussion method can evoke one's motivation in learning and motivation of high learning contributes greatly to elderly caregiver interest in understanding the dental health education materials, so it is easy to implement in a message expected behavior. This is evidenced by Aeni (2016), in their research shows that counseling discussion method can evoke motivation to learn, which affects the interests and learning outcomes.

Someone with a high motivation to have the possibility to participate actively in the activities greater than someone with low motivation. Factors that influence the behavior of people one of which is the motivation of the person, the motivation is the domain that are essential for the activity of elderly caregiver in performing maintenance actions dental health of elderly in a nursing home. Someone with high motivation, have a tendency to be active compared with respondents who have low motivation will have a tendency to be inactive. Motivation is a psychological process that generates, directs and perseverance in performing voluntary actions aimed at achieving goals.

Attitude elderly caregiver in Elim nursing home given dental health education with the lecture method of the score of Pre test to Post test-1, Post test- 1 to the Post test- 2 and Pre test to Post-test 2 showed a significant increase in the attitude $(p<0,05)$. Improved attitudes elderly caregiver in Pengayoman nursing home given dental health education with discussion method, the value of the attitude of Pre test to Post-test 1 showed no significant increase ( $p=$ 0.432), the value of attitude of Post test- 1 to the Post test- 2 and Pre Post test to test- 2 showed a significant increase in the attitude $(p<0.05)$ (Table 2).

Elderly caregiver attitude score in both groups showed a significant increase $(p<0.05)$, but the value to the Pre-test to Post test 1 did not experience a significant increase $(p=$ 0.432). This was caused elderly caregiver slow in responding to the message, so the change in attitude is not as expected. Attitude is very important behavioral domains that are divided into three areas, namely knowledge, attitude, skills (psychomotor). Attitude is an evaluation 
of the positive or negative individuals against the performance of a particular behavior, people will change their minds after receiving information/knowledge understood well (Ghahremani, 2012; Fibriana, 2013; and Hikmawati, 2016), someone with a good attitude to have the possibility of for active eight times higher.

Dental health education aims to change attitudes and behavior of individuals, families, groups, communities in the field of maintenance of oral hygiene as something of value in society. The process of changing the behavior of each individual is different, some are fast and some are slow, depending on the individual's internal response. The behavior change process begins with: 1) the emergence of individual consciousness to the response, 2) raised attention to the response after people raised awareness, 3) the evaluation phase by weighing the profit and loss if the response implemented, 4) people began to try, it would receive if the response is considered beneficial and refused if the response is considered detrimental, 5) individuals receive (adoption) when the response is considered advantageous and beneficial (Suryoputro, 2006). The behavior change process required in order to change the target was not solely due to the addition of knowledge alone, but it is expected also to a change in attitude at the same time steady skills that lead to action or work better, productive and profitable. Manifestations attitudes can't be seen directly, but can only be interpreted in advance of behaviors that are closed. Attitude is still a closed reaction, not an open reaction or behavior that open.

Elderly caregiver slowness in responding to the message, caused by excessive duty burden of elderly caregiver, because it serves the elderly in nursing home for 24 hours, so make elderly caregiver tired. Such conditions affect the ability and activeness of elderly caregiver to perform maintenance actions oral hygiene, so the response in determining the attitude to be blocked. It fits opinions of Yuni (2015), which say that the ability or activity of an individual to do something effect on attitude formation process.

Elderly caregiver attitude change requires a long time, since before the adoption of behavior in the form attitudes requires a belief and confidence. In the cycle attitude has interrelated components: trust, confidence, ideas and concepts to an object as well as the emotional life and tendency to act. The slow change in attitude elderly caregiver after dental health education are not likely due to the confidence and trust to adopt response. Dental health education is done to spread the message, to instill confidence so that people are not only aware, know and understand but also willing and able to do a suggestion that has to do with health.

Score skills of elderly caregiver in Elim nursing home given dental health education with the lecture method, the score of the pretest to post-test-1, and a pre-test to post-test 2 had significant increased in the skills ( $p$ $<0.05$ ), the score of skills post-test 1 to posttest 2 did not experience a significant increase ( $p=0.203)$. Improved skills elderly caregiver in Pengayoman nursing home given dental health education by using the method of discussion, the score of pre-test to post-test-1, post test-1 to post test- 2 and pre-test to post-test- 2 had significant increase of the skills $(\mathrm{p}<0.05)$ (Table 2)

No increase in the value of the skills of the lecture group posttest- 1 to posttest- 2 due to busyness Elderly caregiver in everyday activities so it is not ready to receive information that affects the inability elderly caregiver in learning the practice of oral hygiene maintenance. Skills are outcomes after individuals have the knowledge and attitudes, some of the things that cause results low learning are: 1) the target is less prepared to absorb the lessons, 2) lack of knowledge of speaker of innovative learning, 3) speaker is still taught by using conventional learning method (Nuryanti, 2013). Further said that 1) the education of students did not attempt themselves to find solutions, so as not to produce knowledge that is really meaningful, 2) a speaker is more concerned with the outcome of the learning process. Consequently, learning becomes meaningful, learners will have difficulty in solving the wider problem and in everyday life, 3) learning method applied by the speaker is still dominated by lecture method that are knowledge alone (Nuryanti, 2013)

Changes skills to produce specific health 
Table 3. The Mean Difference in Test Results Between Groups of Elderly Dental Hygiene Lectures and Discussion Groups

\begin{tabular}{|c|c|c|c|c|c|c|c|c|}
\hline \multirow{3}{*}{ Groups } & \multicolumn{4}{|c|}{ Elderly dental health } & \multicolumn{4}{|c|}{ Cleanliness Denture } \\
\hline & \multicolumn{2}{|c|}{ Lecture } & \multicolumn{2}{|l|}{ Discussion } & \multicolumn{2}{|c|}{ Lecture } & \multicolumn{2}{|l|}{ Discussion } \\
\hline & $\begin{array}{l}\text { Mean } \\
\text { difference }\end{array}$ & $\mathrm{P}$ & $\begin{array}{l}\text { Mean } \\
\text { difference }\end{array}$ & $\mathrm{p}$ & $\begin{array}{l}\text { Mean } \\
\text { difference }\end{array}$ & $\mathrm{p}$ & $\begin{array}{l}\text { Mean } \\
\text { difference }\end{array}$ & $\mathrm{p}$ \\
\hline $\begin{array}{l}\text { Pretest - } \\
\text { Posttest-1 }\end{array}$ & 1,080 & 0,000 & 1,140 & 0,000 & 0,812 & 0,081 & 0,960 & 0,013 \\
\hline $\begin{array}{l}\text { Posttest-1- } \\
\text { Posttest-2 }\end{array}$ & 0,416 & 0,000 & 0,919 & 0,000 & 0,362 & 0,141 & 0,451 & 0,043 \\
\hline $\begin{array}{l}\text { Pretest } \\
\text {-Posttest-2 }\end{array}$ & 1,496 & 0,000 & 2,020 & 0,000 & 1,175 & 0,035 & 1,411 & 0,004 \\
\hline
\end{tabular}

Source : Primary Data

behaviors take a long time. For the ability of the elderly caregiver must be practiced continually, so it becomes a habit and people who used to perform a health behavior will become skillful. It fits opinion of Eunice (2012), which states that changes in skills or health practices still take many years to have an impact.

Related behavior habits that can lead to a positive and negative, so that the elderly who regularly perform maintenance of oral hygiene can prevent disease and slow the degenerative process in the mouth

Table 3 shows that the increase in dental hygiene elderly to group lectures and group discussions on the score of pretest to posttest- 1 , post test- 1 to post test- 2 and pretest to posttest-2 had a significant increase $(\mathrm{p}<0,05)$. But when viewed from a mean value of the difference in the discussion group had a higher score than the lecture group.

In the discussion of methods made possible bidirectional communication between elderly caregiver mutual dialogues with the elderly, making it easier for the elderly to explore for deeper understanding. With good knowledge, elderly more understand to the material maintenance of oral hygiene, so as to practice the correct way to brush teeth. Elderly caregiver embed elderly in Pengayoman nursing home to tooth brushing habits while taking a bath, habits of elderly in a nursing home shower 2 times a day, so it automatically brushing teeth two times a day. Although less precise when brushing your teeth but have a positive impact in reducing the accumulation of plaque and food debris in the oral cavity. Routines are implanted elderly caregiver make the elderly become skillful. This is evidenced by Budisuari (2010) in her research that the skills trained through repeated practice will become a habit.

Habits and independence of elderly in maintaining oral hygiene can't be separated from elderly caregiver role in implementing the parenting to the elderly by train elderly brushing teeth repeatedly and continuously. In addition, increase the value of dental hygiene influenced by the ability of elderly caregiver in conveying or transferring knowledge and skills to the elderly. Based on the knowledge and skills possessed, elderly caregiver teaching ways of brushing your teeth using a variety of props that are tailored to the characteristics of the target, so that the elderly easy to accept and understand that ultimately is able to practice the maintenance of teeth and mouth independently. It fits the opinion of Widiatmoko (2012), which says that the success of an educational intervention influenced among others by means of learning, handouts, media variations or props used learning, training methods and the ability of the facilitator.

Table 3 shows that, the resulting increase in the value of the elderly denture hygiene for lecture group did not experience a significant increase ( $p>0.05$ ), particularly pre-test to posttest-1, post-test 1 to post-test 2 however score of pre-test to post-test 2 had significant increase of denture hygiene $(p=0.035)$. Group discussion on the score of the pre-test to post-test-1, post- 
test 1 to post-test 2 and pre-test to post-test 2 increases in score significantly $(p<0.05)$.

No increase in the value of the group denture hygiene lecture possible because elderly caregiver do not have the ability to transfer of knowledge and transfer of skills. Limited knowledge sources in presenting the material will hinder the adoption of an understanding of the target. The inability of speakers not only measured the minimum mastery of the material, but also influenced by the ability of speakers in developing health education methods. Elderly caregiver as a counselor should be able to develop counseling methods in accordance with the characteristics of elderly, so that the message can be received well. Inability elderly caregiver in conveying the message and develop methods contrary to its role as an educator to provide complete information to increase knowledge through appropriate methods, to target capable of carrying out the expected message. As an educator, serves as a facilitator giver, elderly caregiver motivator and to actively drive the elderly in oral hygiene maintenance (Sistiarani, 2013)

Increased score of denture hygiene in group discussions due to the elderly in Pengayoman nursing home have the habit of removing the denture when going to sleep. Before acquiring knowledge denture care efforts undertaken by removing only the elderly without washing then immersed. Despite the efforts of the maintenance done wrong, but have an impact on reducing the accumulation of plaque and build-up of food debris that cause a disease of the oral cavity. Denture should be adequately maintained to prevent disease in the oral cavity. Hygiene maintenance purposes removable denture is so durable, prevents the accumulation of plaque, maintaining oral health and prevent oral diseases other (Rahmayani, 2013).

Dentalhealtheducationaimedatchanging behaviors and habits in the maintenance of oral hygiene. Discussion method is considered effective by elderly caregiver, because at the time of delivery of material more dialogue and lead to the practice or demonstration, thereby increasing elderly caregiver understanding of the material. Elderly caregiver make the transfer of skills to the elderly on ways to care for removable denture repeatedly. According Gopdianto (2015), dental health education with the provision of information, followed by plenty of exercise will effectively changing behavior and increasing public understanding. The way to maintenance removable denture covers how storage and cleaning. Cleaning can be done by brushing dentures with a toothbrush and toothpaste. In addition to brushing dentures are also recommended soaked in cleaning solution according to the rules of denture cleaning agents are used. Later on during sleep is recommended to remove the denture and stored in a container of water (Bagaray, 2014).

There was no significant difference $(\mathrm{p}>$ 0.05 ) in observations on knowledge, attitudes and skills of elderly caregiver conducted 1 month after being given treatment (posttest 2) in both treatment groups. Lecture and discussion is a conventional method which is delivered directly to the target, so that it contacts between speakers and targets. When the target can contact directly with a speaker, there will be an effective communication process.

According Qurniawati (2013), some of the reasons the lecture method is often used: 1) a method that is cheap and easy to do.

Table 4. Mean and Standard Deviation Post Test-2 (1 Month Later) of Knowledge, Attitudes and Skills of Elderly Caregivers in Group Lectures and Discussion Groups

\begin{tabular}{llllll}
\hline Groups & $\begin{array}{l}\text { Post test 2 groups } \\
\text { lecture }\end{array}$ & & Discussion & & P \\
& Mean difference & SD & Mean difference & SD & \\
\hline Pengetahuan & 27,89 & 3,123 & 29,00 & 2,226 & 0,185 \\
Sikap & 76,39 & 5,972 & 72,67 & 7,783 & 0,087 \\
Keterampilan & 31,39 & 2,146 & 32,50 & 2,246 & 0,114 \\
\hline
\end{tabular}

Source : Primary Data 
Cheap in a sense, the lecture does not require complex equipment and supplies, 2) to reach the presentation of learning materials more widely. This means a lot of learning materials that can be summarized and explained the basics just in a short time, 3) focused only on the main points of the core material, in a sense, a spekear can organize the material where the priorities according to the needs and goals of indicators to be achieved ,4) the speaker can monitor the state of the class, as a class entirely its responsibility when delivering learning materials, 5) organizing the class becomes more simple and practical, and therefore does not require the preparations of all sorts. This is evidenced Musfiroh (2014), in her research proved that the lecture method in the extension affect the change in attitude of the respondent. Though relatively conventional, discussion method favored target because it is more interactive between speakers and targets. Zulaekah (2012), showed in her study that the discussion method is effective in improving knowledge of child nutrition. Excess discussion method when applied in teaching and learning activities, namely: 1) stimulates the target to be more creative, especially in providing ideas, 2) training to get used to brainstorm solve any problems, 3) training objectives for expressing opinions or ideas verbally (Setiawan, 2008).

\section{Conclusion}

The results of this study can be concluded that dental health education with discussion method to elderly caregiver more effective in improving knowledge in the field of dental and oral hygiene maintenance of elderly compared with the lecture method; Dental health education with the lecture method more effective in improving elderly caregiver attitude towards oral hygiene maintenance of elderly compared to the method of discussion; Dental health education with the lecture method is more effective in improving the skills elderly caregiver in maintaining oral hygiene elderly compared to the method of discussion; Dental health education with discussion method is more effective in improving the cleanliness of natural teeth and dentures elderly compared with the lecture method.

\section{References}

Aeni, Suci RN, 2016. Peningkatan Motivasi
Belajar Kimia Siswa Sekolah Menengah Menggunakan Metode Koligatif Kemas Kreatif (k3). Jurnal Kimia dan Pendidikan. 1, (1).

Amanah,S. 2007. Makna Penyuluhan dan Transformasi Perilaku Manusia. Jurnal Penyuluhan, 3 (1)

Bagaray, DA. Ni Wayan Mariat,. Leman, MA. 2014. Perilaku Memelihara Kebersihan Gigi Tiruan Lepasan Berbasis Akrilik Pada Masyarakat Desa Treman Kecamatan Kauditan, Jurnal e-Gigi. PAAI, 2 (2)

Budisuari, 2010. Hubungan Pola Makan Dan Kebiasaan Menyukat Gigi Dengan Kesehatan Gigi Dan Mulut (Karies) Di Indonesia. Buletin of Health System Research, 13 (1)

Elizabeth, L. 2010 Tuberculosis Knowledge, Attitude And Beliefs among Caronilians at Increased Risk of Infection. NC Medical Journal, 69 (1)

Eunike R. Rustiana, Cahyati WH. 2012. Stress Kerja Dengan Pemilihan Strategi Coping, Jurnal Kesehatan Masyarakat, 7 (2) : 149-155

Fibriana, A.I, 2013. Keikutsertaan Pelanggan Wanita Pekerja Seks Dalam Voluntary Conseling And Testing (VCT). Jurnal kesehatan masyarakat. Kemas 8 (2) : 161-165

Frenkel, H., Harvey, I., Newcombe,R.G., 2001, Improving Oral Health in Institutionalised Elderly People By Educating Caregivers: a Randomised Controlled Trial, Munksgaard.

Ghahremani, L., \& Nikmani, S. (2012). The Prediction of Physical Activity Intention and Behavior in Elderly Male Residents of a Nursing Home: A Comparison of Two Behavioral Theories. Iranian Journal of Medical Science, 37 (1) : 23-21.

Gopdianto, A. J.R, Rattu M., Ni Wayan Mariati, 2015.Mulut Dan Perilaku Menyikat Gigi Anak Sd Negeri 1 Malalayang. Jurnal e-Gigi. PAAI, 3 (1)

Hamidah. Zulaekah,S. Mutalazimah. 2012. Penyuluhan Gizi Dengan Media Komik Untuk Meningkatkan Pengetahuan Tentang Keamanan Makanan Jajanan, Jurnal Kesehatan Masyarakat, 8 (1) : 67-73

Hidayati, NA. 2014. Penerapan Bermain Balliret Untuk Meningkatkan Hasil Belajar Gerak Dasar Loncat Pada Siswa Kelas IV Semester II SDN Bugel 02 Kecamatan Sidorejo Kota Salatiga Tahun Pelajaran 2012/2013. Journal of physical education, sport, health and recreations, 3 (9)

Hikmawati, Z. Yasmani, Sya'ban, AR. 2016. Pengaruh Penyuluhan Dengan Media Promosi Puzzel Gizi Terhadap Perilaku Gizi Seimbang Pada Siswa Kelas V Di SD Negeri 06 Poasia Kota 
Kendari tahun 2016. Jurnal Penyuluhan, 3 (1)

Kaur, G. 2011. Study and Analysis of Lecture Model of Teaching. International Journal of Educational Planning \& Administration, 1 (1) : 9-13.

Lumentut R A N, Paulina N. Gunawan, Mintjelungan CN. 2013. Status Periodontal Dan Kebutuhan Perawatan Pada Usia Lanjut. Jurnal e-Gigi.PAAI, 1 (2)

Marson, S. M., \& Powell, R. M. 2014. Goffman and the Infantilization of Elderly. Journal of Sociology \& Social Welfare, 51 (4) : 143-158.

Molton, R. I., \& Terrill, L. A. 2014. Overview of Persistent Pain in Older Adults. American Psychological Association, 69 (2) : 197-207.

Musfiroh, M. Wisudaningtyas B L. 2014.Penyuluhan Terhadap Sikap Ibu Dalam Memberikan Toilet Training Pada Anak Jurnal Kesehatan Masyarakat KEMAS, 9 (2)

Nuryanti, E. 2013. Perilaku Pemberantasan Sarang Nyamuk Di Masyarakat, Jurnal Kesehatan Masyarakat. 9 (1) : 15-23

Petersen, et al. 2010. Global oral health of older people - Call for public health action. Community Dental Health, 27 : 257-268.

Qurniawati A, Sugiharto, Saputro ANC. 2013. Numbered Head Together (Nht) Dengan Media Kartu Pintar Dan Kartu Soal Terhadap Prestasi Belajar Siswa Pada Materi Pokok Hidrokarbon Kelas X Semester Genap Sma Negeri 8 Surakarta Tahun Pelajaran 2012/2013. Jurnal Pendidikan Kimia (JPK), 2 (3)

Rahmayani, L. Herwanda, Idawani, M. 2013. Perilaku Pemakai Gigi Tiruan Terhadap Pemeliharaan Kebersihan Gigi Tiruan Lepasan. Jurnal PDGI, 62 (3)

Rahman, F., Khalil, J. K., Jumani, N. J., Ajmal, M., Malik, S., \& Sharif, M. 2011. Impact of Discussion Method on Students Performance. International Journal of Business and Social Scienc, 2 (7) : 84-94.

Rizki, NA. 2012. Metode Focus Group Discussion Dan Simulation Game Terhadap Peningkatan Pengetahuan Kesehatan Reproduksi, Jurnal
Kesehatan Masyarakat, KEMAS 8 (1) : 23-29. Setiawan, I Gusti Agung Nyoman, 2008. Penerapan Pengajaran Kontekstual Berbasis Masalah Untuk Meningkatkan Hasil Belajar Biologi Siswa Kelas X Sma Laboratorium Singaraja. Jurnal Penelitian dan Pengembangan Pendidikan. Vol. 2(1) : 42-59

Sistiarani C, Nurhayati S, Suratman. 2013. Peran Kader Dalam Penggunaan Buku Kesehatan Ibu Dan Anak. Jurnal Kesehatan Masyarakat, KEMAS, 8 (2) : 99-105

Suryoputro, A. Nicholas J. F. Shaluhiyah, Z. 2006. Faktor-Faktor Yang Mempengaruhi Perilaku Seksual Remaja Di Jawa Tengah: Implikasinya Terhadap Kebijakan Dan Layanan Kesehatan Seksual Dan Reproduksi. Jurnal Makara, Kesehatan, VOL. 10, NO. 1, JUNI 2006: 29-40 Teddlie, C., \& Yu, F. 2007. Mixed Methods Sampling: A Typology With Examples. Journal of Mixed Methods Research, 1 (77) : 77-100.

Tjeckyan, S. 2014. Angka kejadian dan faktor risiko Hipertensi Di Kota Palembang.Jurnal Kedokteran Dan Kesehatan, 1

Wawan. 2011. Pengetahuan, Sikap dan Perilaku Manusia. Yogyakarta : Nuha Medika

Webster, S. R. 2015. In defence of the Lecture. Australian Journal of Tgeacher Education, 40 (10) : 87-105.

White, H., \& Sabarwal, S. 2014. Quasi-Experimental Design and Methods. Florence: United Nations Children's Fund (UNICEF).

Widiatmoko, A. 2012 Pengembangan Perangkat Pembelajaran Ipa Terpadu Berkarakter Menggunakan Pendekatan Humanistik Berbantu Alat Peraga Murah. Jurnal Pendidikan IPA Indonesia, 2 (1)

Yuni P, Irwan T R, Akhmadi, 2015. Pendidikan Seksual Dan Perilaku Pemenuhan Kebutuhan Seksual Pasangan Masa Kehamilan. Jurnal Kesehatan Masyarakat, KEMAS 10 (2)

Zulaekah, S. 2012. Efektivitas Pendidikan Gizi Dengan Media Booklet Terhadap Pengetahuan Gizi Anak SD.Jurnal Kesehatan Masyarakat KEMAS, 7 (2) 